\title{
ABCG subfamily (version 2019.4) in the IUPHAR/BPS Guide to Pharmacology Database
}

Ian Kerr ${ }^{1}$

1. University of Nottingham, UK

\begin{abstract}
This family of 'half-transporters' act as homo- or heterodimers; particularly ABCG5 and ABCG8 are thought to be obligate heterodimers. The ABCG5/ABCG heterodimer sterol transporter structure has been determined [4], suggesting an extensive intracellular nucleotide binding domain linked to the transmembrane domains by a fold in the primary sequence. The functional ABCG2 transporter appears to be a homodimer with structural similarities to the ABCG5/ABCG8 heterodimer [7].
\end{abstract}

\section{Contents}

This is a citation summary for ABCG subfamily in the Guide to Pharmacology database (GtoPdb). It exists purely as an adjunct to the database to facilitate the recognition of citations to and from the database by citation analyzers. Readers will almost certainly want to visit the relevant sections of the database which are given here under database links.

GtoPdb is an expert-driven guide to pharmacological targets and the substances that act on them. GtoPdb is a reference work which is most usefully represented as an on-line database. As in any publication this work should be appropriately cited, and the papers it cites should also be recognized. This document provides a citation for the relevant parts of the database, and also provides a reference list for the research cited by those parts.

Please note that the database version for the citations given in GtoPdb are to the most recent preceding version in which the family or its subfamilies and targets were substantially changed. The links below are to the current version. If you need to consult the cited version, rather than the most recent version, please contact the GtoPdb curators.

\section{Database links}

ABCG subfamily

http://www.guidetopharmacology.org/GRAC/FamilyDisplayForward?familyld=155

Transporters

ABC8(ABCG1)

http://www.guidetopharmacology.org/GRAC/ObjectDisplayForward?objectld=791

$\mathrm{ABCP}(\mathrm{ABCG})$

http://www.guidetopharmacology.org/GRAC/ObjectDisplayForward?objectld=792

ABCG4 
http://www.guidetopharmacology.org/GRAC/ObjectDisplayForward?objectld=793

ABCG5

http://www.guidetopharmacology.org/GRAC/ObjectDisplayForward?objectld=794

ABCG8

http://www.guidetopharmacology.org/GRAC/ObjectDisplayForward?objectld=795

\section{References}

1. Allikmets R, Schriml LM, Hutchinson A, Romano-Spica V and Dean M. (1998) A human placenta-specific ATP-binding cassette gene (ABCP) on chromosome $4 \mathrm{q} 22$ that is involved in multidrug resistance. Cancer Res. 58: 5337-9 [PMID:9850061]

2. Doyle LA, Yang W, Abruzzo LV, Krogmann T, Gao Y, Rishi AK and Ross DD. (1998) A multidrug resistance transporter from human MCF-7 breast cancer cells. Proc. Natl. Acad. Sci. U.S.A. 95: 15665-70 [PMID:9861027]

3. Kerr ID, Haider AJ and Gelissen IC. (2011) The ABCG family of membrane-associated transporters: you don't have to be big to be mighty. Br. J. Pharmacol. 164: 1767-79 [PMID:21175590]

4. Lee JY, Kinch LN, Borek DM, Wang J, Wang J, Urbatsch IL, Xie XS, Grishin NV, Cohen JC and Otwinowski $Z$ et al.. (2016) Crystal structure of the human sterol transporter ABCG5/ABCG8.Nature 533: 561-4 [PMID:27144356]

5. Miyake K, Mickley L, Litman T, Zhan Z, Robey R, Cristensen B, Brangi M, Greenberger L, Dean M and Fojo $T$ et al.. (1999) Molecular cloning of cDNAs which are highly overexpressed in mitoxantrone-resistant cells: demonstration of homology to ABC transport genes. Cancer Res. 59: 8-13 [PMID:9892175]

6. Ozvegy C, Litman T, Szakács G, Nagy Z, Bates S, Váradi A and Sarkadi B. (2001) Functional characterization of the human multidrug transporter, ABCG2, expressed in insect cells. Biochem. Biophys. Res. Commun. 285: 111-7 [PMID:11437380]

7. Taylor NMI, Manolaridis I, Jackson SM, Kowal J, Stahlberg H and Locher KP. (2017) Structure of the human multidrug transporter ABCG2. Nature 546: 504-509 [PMID:28554189] 